\title{
PENGLIBATAN ORANG CINA DALAM GERAKAN KOMUNIS DI SARAWAK, 1924-1974
}

\author{
Ho Hui Ling
}

\begin{abstract}
The beginning of the Communist movement in Sarawak could be traced back to the 1924 when the Kuomintang (KMT) branch was established in Sarawak. In the Sarawak communist movement, almost all involved were Chinese, and they were the largest group sympathetic to the communist cause. They were exposed to communist teachings through Chinese schools, periodicals, labour and plantation unions, and political establishments. The communist movement then turned to armed struggle when the Malaysian plan was announced, and then the Federation of Malaysia was formed on 16 September 1963. However, the spread of communist ideology among the Chinese and their involvement in the movement alarmed the government, as the Chinese were an important group, especially in the development of economy and because they formed the second largest ethnic community in Sarawak. The government acted to limit communism from spreading further in Sarawak, by launching military operations and controlling newspaper publications, Chinese schools, and political organisations and activities. The communist problem in Sarawak finally faded with the success of the government-launched Sri Aman Operation in 1974.
\end{abstract}

\section{Pengenalan}

Masyarakat Sarawak terdiri daripada penduduk berbilang kaum. Tiga kaum utama ialah orang Dayak, Cina dan Melayu. Orang Cina 
membentuk kumpulan etnik yang kedua terbesar di Sarawak. Kawasan tumpuan kebanyakan orang Cina adalah di kawasan bandar dan pekan di seluruh negeri Sarawak. Kecuali orang Cina di kawasan Bau yang bekerja sebagai pelombong emas, umumnya orang Cina masuk ke Sarawak sebagai petani pada asalnya. Kemudian mereka turut mengambil bahagian dalam penanaman tanaman komersial dan menjalankan perniagaan serta akhirnya terlibat dalam sektor pembalakan dan perlombongan minyak. Bilangan orang Cina bertambah dengan kadar yang stabil sehingga mereka membentuk kumpulan etnik yang kedua terbesar di Sarawak selepas kaum Dayak. Mereka bukan sahaja menguasai sektor-sektor ekonomi penting tetapi kemudian juga mengambil bahagian dalam gerakan komunis yang bermula pada tahun 1920-an di Sarawak.

Semua sedia maklum bahawa majoriti yang terlibat dalam gerakan komunis di Sarawak adalah orang Cina. Keadaan ini disebabkan pertalian rapat antara orang Cina dengan China yang membolehkan fahaman komunis senang tersebar dalam kalangan komuniti itu. Orang Cina sejak kedatangan mereka ke Sarawak pada abad ke-19 sehingga 1950-an, mereka masih terpengaruh dengan perkembangan politik di negara China termasuklah gerakan komunis. Tambahan pula, orang Cina masih terikat dengan pendidikan Cina di mana sukatan pelajaran dan buku teks dibawa dari China serta guru diambil dari China atau mereka yang mendapat pendidikan di China. Keadaan tersebut menyebabkan pandangan mereka masih cenderung ke arah perubahan politik dan perkembangan fahaman politik di China. Dalam keadaan itu, fahaman komunis yang mula berkembang di China pada awal abad ke-20 itu turut meninggalkan kesan ke atas masyarakat Cina di Sarawak. Disebabkan itu, dalam perkembangan komunis di Sarawak tidak dapat dipisahkannya dengan orang Cina. Mereka adalah sasaran utama komunis dalam memperluas kegiatan dan mendapatkan sokongan bagi mencapai matlamat perjuangan komunis di Sarawak. Berpandukan perkembangan di atas, tulisan ini bertujuan untuk meneliti pergerakan komunis di Sarawak dan penglibatan orang Cina dari tahun 1924 sehingga 1974.

\section{Penglibatan Orang Cina Dalam Gerakan Komunis, 1924-1962}

Kawasan tumpuan utama pergerakan komunis di Sarawak adalah di Bahagian Pertama dan Bahagian Ketiga. Dari segi kedudukan geografi, kedua-dua bahagian ini bersempadan dengan Kalimantan dan ini memudahkan gerila komunis melarikan diri untuk bersembunyi di kawasan sempadan apabila diburu oleh pasukan keselamatan. Tambahan pula, Bahagian Ketiga terletak jauh dari pusat pentadbiran 
di Kuching dan ini memudahkan gerila komunis bergerak dengan lebih selamat. Begitu juga, terdapat banyak kawasan di Bahagian Pertama dan Bahagian Ketiga khasnya pada ketika itu yang masih diliputi oleh hutan tebal. Keadaan geografi ini memberi kemudahan kepada komunis untuk bergerak, melarikan diri dan bersembunyi serta sukar dikesan oleh pasukan keselamatan. Selain itu, sokongan daripada penduduk tempatan lebih mudah diperoleh oleh komunis di kawasan itu. Kedua-dua Bahagian tersebut mempunyai penduduk Cina yang ramai bukan sahaja di bandar tetapi juga di kawasan pedalaman. Penduduk itu berpotensi untuk dipengaruhi dan dijadikan penyokong serta pembekal keperluan harian komunis sama ada melalui tekanan atau pujukan. Selain Bahagian Pertama dan Ketiga, Bahagian Keempat juga dilaporkan menjadi kawasan penting komunis. Ini kerana di Bahagian Keempat juga terdapat ramai orang Cina dari pelbagai dialek yang boleh dipergunakan untuk menyokong pergerakan komunis. Dengan itu, jelas bahawa faktor orang Cina turut memainkan peranan penting dalam mempengaruhi gerakan komunis di Sarawak.

Perkembangan gerakan komunis di Sarawak pada peringkat awal adalah amat dipengaruhi oleh perubahan politik yang berlaku di China. Fahaman komunis telah dapat dikesan di Sarawak pada awal tahun 1920-an. Mengikut rekod Pejabat Tanah Jajahan, sehingga tahun 1924, cawangan Kuomintang (KMT) telah ada di Sarawak di samping di merata tempat di Tanah Melayu. ${ }^{1}$ Ibu pejabat KMT adalah di negara China dan KMT telah membentuk pakatan dengan Parti Komunis China (PKC) di China pada tahun 1924, iaitu Barisan Bersatu KMT-PKC. Pakatan itu telah membolehkan komunis dan KMT bergerak bersama dalam mempengaruhi penduduk Cina baik di China mahupun di seberang laut. Dengan itu, gerakan awal untuk menyebarkan fahaman komunis telah bermula melalui cawangan KMT yang ditubuhkan di Sarawak. Pada sekitar tahun 1927, Barisan Bersatu KMT-PKC di China telah berpecah. Pengikut-pengikut komunis dari China telah melarikan diri ke Sarawak apabila mereka diburu oleh pihak KMT di China. ${ }^{2}$ Golongan ini kemudian telah menyebarkan pengaruh komunis dalam kalangan orang Cina yang pada ketika itu sentiasa memberi perhatian kepada perkembangan di China. Walaupun pada peringkat awal tiada satu gerakan yang berbentuk 'terbuka', namun benih-benih awal komunisme mulai tersemai dalam kalangan orang Cina.

Ketika Perang Dunia Kedua meletus, sekumpulan orang Cina berpendidikan dan berfikiran moden dari China telah masuk ke Kuching. Antara mereka ialah Wu Tshan, Chin Shao Thong dan beberapa orang lagi. Mereka menggalakkan gerakan menentang penindasan penduduk daripada pemerintah. Wu Tshan pernah mengajar di sebuah sekolah Cina pada awal tahun 1941 dan dari situ juga tersebarnya pengaruh 
komunis dalam kalangan pelajar Cina di Sarawak. Gerakan komunis yang lebih tersusun di Sarawak bermula pada zaman pendudukan Jepun. Zaman pendudukan Jepun antara Disember 1941 hingga Ogos 1945 telah membawa kesan kepada kebangkitan perasaan melawan Jepun secara ketenteraan. Kegiatan komunis pada ketika itu banyak disertai oleh petani-petani miskin berbangsa Cina khasnya yang tertarik dengan idea perjuangan pergerakan komunis, iaitu masyarakat sosialis dan tanpa kelas. Majoriti daripada mereka yang memberi sokongan kepada pihak komunis ialah petani-petani Hakka yang tinggal di kawasan Batu Kawa di luar bandar Kuching. ${ }^{3}$ Rata-rata mereka percaya bahawa melalui gerakan komunis akan dapat mengubah nasib dan membaiki kehidupan mereka.

Dengan itu, sebuah pertubuhan berunsur komunis yang pertama, iaitu Liga Anti-Fasis Sarawak (Sarawak Anti-Fascist League/SAFL) dibentuk pada tahun 1941 untuk menjalankan gerakan menentang pentadbiran Jepun. Penubuhan SAFL tidak begitu aktif kerana tidak diketahui ramai pada ketika itu. Gerakan SAFL adalah berpusat di Bahagian Pertama Sarawak. Pada tahun 1942, nama SAFL telah ditukarkan kepada Liga Pembebasan Nasional Sarawak (Sarawak National Liberation League) atau SNLL dan digunakan sepenuh oleh komunis untuk mengembangkan pengaruhnya. ${ }^{4}$ Pertubuhan itu turut merancang untuk menubuhkan Overseas Chinese Young Men's Association selepas perang tamat. Namun begitu, SNLL telah berpecah dan dibubarkan apabila Jepun menyerah kalah. Justeru itu, selepas Perang Dunia Kedua, pihak kerajaan berasa bimbang tentang perkembangan komunis dan penyerapan fahaman komunis dalam kalangan orang Cina di Sarawak. Walaupun fahaman itu bukan berasal dari tempatan tetapi perkembangannya boleh mempengaruhi kestabilan politik dan keselamatan negeri Sarawak.

Selepas perang, penerbitan sebuah akhbar Cina yang baru telah bermula, iaitu Chung Hua Kung Pao di Kuching. Penerbit dan editornya adalah orang Cina dari China. Akhbar itu menjadi saluran penting komunis sehingga diharamkan oleh kerajaan pada tahun 1951. Di antara tahun 1949 dan 1950, kumpulan Hsueh Hsih (communist indoctrination) wujud pertama sekali di Kuching untuk mendoktrinasikan fahaman komunis dalam kalangan penduduk khasnya orang Cina seperti pelajar sekolah dan belia. Daripada kumpulan itulah lahir Student Self-Governing Societies yang merupakan tarikan awal dalam kalangan pelajar Cina di Sarawak. Mereka bergerak aktif terutama sekali di Chung Hua Middle School di Kuching. Di sekolah itu juga telah lahirnya dua orang pemimpin utama yang kemudian menjadi perintis kepada penubuhan parti komunis di Sarawak. Mereka ialah Bong Kee Chok dan Wen Ming Chyuan. ${ }^{5}$ 
Perkembangan komunis dalam kalangan orang Cina Sarawak berkait rapat dengan pengaruh komunis China. Pergerakan komunis di Sarawak muncul dengan giat berikutan dengan kejayaan pembentukan kerajaan komunis di China. Penubuhan Republik Rakyat China (RRC) telah diisytiharkan di Peking pada bulan Oktober 1949. Pembentukan RRC disambut dengan meriah oleh orang Cina Sarawak yang bermula di Kuching pada 28 Januari 1950, seterusnya di Bau, Sibu, Miri dan seluruh Sarawak. Kejayaan RRC itu telah meningkatkan semangat nasionalisme orang Cina di Sarawak terutamanya dalam kalangan golongan belia. Pencapaian RRC juga dilihat sebagai pendorong kepada pihak komunis di Sarawak supaya berjuang dengan lebih aktif untuk mencapai cita-cita mereka sebagaimana kejayaan komunis di China.

Keadaan bertambah giat apabila pada tahun 1950, RRC menghantar wakil untuk menyeru orang Cina Seberang Laut supaya terus menyokong China. Akibatnya seramai 200 hingga 300 orang Cina di Kuching dan Sibu telah pulang ke China. Keadaan itu turut mendorong golongan pemuda Cina menyusun sebuah persatuan persahabatan proPeking yang dikenali sebagai Sarawak Overseas Chinese Democratic Youth League (SOCDYL) pada 21 Oktober 1951. Persatuan ini dipimpin oleh dua orang Cina tempatan, iaitu Wen Ming Chyuan dan Teo Yong Jin. Berdasarkan dokumen komunis di Sarawak, SOCDYL dikatakan adalah pertubuhan komunis pertama yang wujud selepas perang. Tujuannya ialah untuk menyebarkan fahaman komunis dan mengeksploitasi keadaan yang boleh menguntungkan perjuangan komunis. Dalam hal itu, SOCDYL memberi keutamaan untuk mempengaruhi golongan belia dan pelajar berbangsa Cina serta menjalin hubungan dengan golongan kiri radikal di Singapura, iaitu golongan anti-British. Namun begitu, kerajaan British telah mengisytiharkan darurat pada 1952 di Bahagian Pertama Sarawak dan disusuli dengan operasi ketenteraan untuk melemahkan pergerakan komunis. Tindakan kerajaan Sarawak untuk menyekat Liga tersebut daripada bergerak secara terbuka di Sarawak telah membawa kepada pembubaran SOCDYL. ${ }^{6}$

Bagaimanapun, komunis masih terus bergerak di Sarawak dan kemudian menubuhkan Sarawak Liberation League (SLL) pada Julai 1953. SLL ditubuhkan dan dipimpin oleh Teo Yong Jin dan dibantu oleh Wen Ming Chyuan serta Qiu Li-ben. SLL bertujuan untuk memperkuat barisan perjuangan komunis di Sarawak dengan melancarkan gerakan anti-kolonial. Selain mempengaruhi pelajar sekolah dan belia, mereka mahu menjadikan petani dan pekerja sebagai sasaran kerana kedua-dua golongan ini diperlukan untuk mencapai matlamat perjuangan mereka. Petani dan pekerja boleh diperalatkan untuk menentang kapitalis dan juga imperialis. ${ }^{7}$ Namun begitu, SLL pula kemudiannya diganti oleh sebuah pertubuhan komunis lain iaitu Sarawak Advanced Youth 
Association (SAYA) yang dibentuk pada tahun 1956. SAYA ditubuhkan untuk menghayati dan mengembangkan lagi pengaruh komunis di Sarawak dengan menggalakkan para penyokongnya mempelajari teori Marxisme/Leninisme serta ideologi Mao Tse-tung. ${ }^{8}$ Pembentukan SAYA telah menyediakan peluang kepada komunis untuk menjalankan kegiatannya dengan lebih aktif. Tumpuan diberi kepada kesatuan sekerja, petani, pertubuhan politik, kerja propaganda dan akhbar serta gerakan pelajar. Pemimpin utama SAYA ialah Wen Ming Chyuan, Bong Kee Chok dan adiknya Bong Kee Siaw.

Pertubuhan SAYA dianggap oleh kerajaan Sarawak sebagai Pertubuhan Sulit Komunis (Clandestine Communist Organisation/CCO) atau Sarawak Communist Organisation (SCO). Pada ketika itu, CCO dianggarkan mempunyai keahlian sejumlah lebih kurang 2,500 orang dan dibahagikan kepada jawatankuasa daerah, kawasan dan bahagian yang diletakkan di bawah sebuah jawatankuasa pusat. Matlamat utamanya adalah membebaskan Sarawak daripada belenggu penjajahan dan membentuk sebuah negara komunis yang meliputi Sarawak, Sabah dan Brunei. ${ }^{9}$ Dengan penyatuan itu juga, komunis dapat mewujudkan Parti Komunis Borneo. Matlamat pergerakan komunis tersebut dapat dilihat dalam sebuah dokumen komunis bertajuk "Manifesto on the Establishment of the Borneo Communist Party" yang dirampas oleh pihak kerajaan, yang antara lainnya mencatatkan:

Its objects are to overthrow the British Imperialists' colonial rule; to eradicate thoroughly all the exploiting classes and systems; to establish a completely indepent, democratic, peaceful, prosperous and powerful socialist country; and gradually to attain the highest ideal of mankind-Communist society. ${ }^{10}$

Dalam aktiviti CCO di Sarawak, keanggotaannya adalah orang Cina sebagaimana yang dinyatakan dalam "Report of The Communist Threat \& Local Chinese Problems in Sarawak \& Sabah". ${ }^{11}$ Mereka telah menggunakan pelbagai cara untuk menyebarkan fahaman dan pengaruhnya di Sarawak, guru dan pelajar di sekolah, kesatuan sekerja dan peladang serta akhbar Cina tempatan. Laporan itu juga mencatatkan kawasan utama yang menjadi tumpuan kegiatan CCO di Sarawak juga adalah kawasan tumpuan orang Cina. Kawasan tersebut ialah Jalan Kuching-Serian dan kawasan Bau di Bahagian Pertama yang kebanyakan penduduknya adalah Hakka; kawasan Sibu-BinatangSarikei di tebing Sungai Rejang di Bahagian Ketiga dengan kebanyakan penduduknya Hockchews serta kawasan Miri di Bahagian Keempat Sarawak dengan penduduk Cina pelbagai dialek. ${ }^{12}$ 
Antaranya, sekolah Cina dan pelajar di sekolah menengah Cina menjadi sasaran utama komunis untuk tujuan tersebut. Ini memandangkan sekolah diumpamakan oleh komunis sebagai "tanah yang subur", manakala pelajar dianggap sebagai "perintis dan jambatan" untuk pergerakan subversif itu menjalankan kegiatannya sebagaimana yang dilaporkan dalam Utusan Sarawak bertarikh 28 Julai 1960. ${ }^{13}$ Ini kerana sistem pelajaran Cina yang dibiarkan berkembang sendiri oleh pihak penjajah British di Sarawak telah memberi ruang yang baik untuk komunis mengembangkan pengaruhnya dalam kalangan pelajar melalui aktiviti pengajaran dan pembelajaran dalam kelas serta luar kelas. Misalnya, pelajar sekolah Cina diajar lagu yang menggalakkan mereka menumpukan taat setia kepada "Fatherland", iaitu China Komunis. "Build up our Fatherland as a beautiful garden" merupakan judul sebuah lagu yang bermula dengan baris: "From Peking to distant Sinkiang, the hymn of reconstruction is heard everywhere."14 Manakala, lagu yang berjudul "Fatherland March" biasa dinyanyikan di sekolah rendah Cina. Dengan itu, jelas bahawa lagu-lagu yang dinyanyikan di sekolah Cina itu bertujuan untuk memimpin pelajar agar memberi tumpuan kesetiaan kepada China dan bukan Sarawak.

Sementara itu, lima bintang simbol komunis China, peta China dan simbol komunis yang lain turut dijumpai dalam buku lagu yang kemudian telah dirampas oleh pihak kerajaan. ${ }^{15}$ Tindakan pihak komunis tersebut adalah bertujuan untuk mempengaruhi pemikiran kanak-kanak di sekolah Cina supaya menunjukkan sikap menyokong perjuangan politik di China. Selain itu, pihak komunis juga menganjurkan aktiviti dalam kalangan pelajar seperti perkelahan, permainan, muzik dan aktiviti rekreasi lain bagi melindungi tujuan sebenar mereka dari pengetahuan umum. Secara tidak langsung melalui aktiviti itu, pihak komunis cuba mengawal pemikiran golongan pelajar supaya cenderung ke arah pemikiran komunis. Dengan itu, seterusnya membolehkan komunis merekrut pelajar Cina yang sesuai bagi membantu menjalankan kegiatan komunis. ${ }^{16}$

Pengaruh komunis dalam sekolah Cina juga dapat dilihat melalui penglibatan mereka dalam menimbulkan kekacauan yang berlaku di Sekolah Menengah Chung Hua Kuching pada tahun 1951. Pada tahun 1951, kerajaan mendakwa Persatuan Pelajar Sekolah Menengah Chung Hua Kuching dipengaruhi fahaman komunis. Pihak pengurusan sekolah hilang kawalan terhadap sekolah itu apabila para pelajar mendesak supaya pihak sekolah mempertimbangkan semula keputusan peperiksaan bahasa Inggeris yang majoriti pelajarnya gagal. Sebahagian daripada pelajar itu mula mengadakan demonstrasi dan mengakibatkan seramai 17 orang pelajar dibuang sekolah serta enam orang ditahan. Bagaimanapun, desakan itu membawa kepada pembentukan Lembaga 
Pengurusan Sekolah yang baru pada 17 Januari 1952. SOCDYL yang menyokong pelajar itu juga diisytiharkan sebagai pertubuhan menyalahi undang-undang pada Februari 1952 oleh kerajaan. Berikutnya, pengetua dan lima orang guru Sekolah Chung Hua juga ditahan kerana disyaki terlibat dalam kegiatan tersebut. Manakala, tiga orang guru yang lain pula dibuang negeri. Sekolah Chung Hua kemudian telah diarahkan ditutup pada Ogos $1954 .{ }^{17}$

Pihak komunis juga menyokong akhbar Cina harian di Sarawak sebagai alat propaganda pro-komunis untuk menyebarkan sentimen subversif dalam kalangan penduduk Cina. Akhbar pertama di bawah pengaruh komunis yang muncul selepas perang ialah Chung Hua Kung Pao tetapi penerbitan akhbar ini telah diberhentikan oleh kerajaan pada tahun 1951. Selain itu, terdapat akhbar lain yang turut dipengaruhi komunis. Antaranya, Sibu Chiao Sheng Pao yang percetakannya disekat oleh kerajaan pada tahun 1952, Syn Ming Pao (Sibu) yang dihalang penerbitannya pada tahun 1957 dan Sarawak Peoples' Daily (Miri) dilarang pengeluarannya pada tahun 1962. Di samping itu, Sin Wen Pao di Kuching yang diterbitkan pada tahun 1959, Min Chong Pao di Sibu pada tahun 1960 dan Sa Min Pao di Miri pada tahun 1961 juga didapati adalah di bawah pengaruh komunis. ${ }^{18}$ Penerbitan ketiga-tiga akhbar itu kemudiannya telah diberhentikan oleh pihak kerajaan pada Disember 1962. ${ }^{19}$ Akhbar tersebut disebarkan dan digunakan oleh pihak komunis untuk menyebarkan fahaman komunis di kawasan bandar yang mempunyai penduduk Cina yang ramai.

Dalam menjalankan tugas menyebarkan fahaman komunis dalam kalangan penduduk Cina Sarawak, CCO dibantu dengan bahan penerbitan seperti risalah, majalah dan buku. Ini merangkumi dari buku cerita dan buku bergambar kanak-kanak sehingga kepada buku-buku klasik dan juga dari buku asas sekolah kepada buku yang berkaitan dengan teknik dan sains. Kebanjiran bahan-bahan penerbitan itu dapat membuktikan pihak komunis memberi perhatian dalam menyediakan "alat" yang diperlukan bagi membantu mengembangkan kerja-kerja subversif di Sarawak. Antara contoh penerbitan komunis ialah risalah bertajuk "National Independence", buku kecil Hsueh Hsih, Berita Massa (Masses' News), Berita Pekerja dan Petani (Workers and Farmers' News). Kebanyakan penerbitan komunis itu ditulis dalam bahasa Cina yang bersesuaian dengan dasar $\mathrm{CCO}$ yang lebih mementingkan orang Cina sebagai sasaran mereka. ${ }^{20}$

Turut dilaporkan bahawa pihak polis telah menjumpai kira-kira 300 buah buku komunis yang termasuk dalam senarai larangan dalam satu serbuan di kawasan Batu 17 Jalan Kuching-Serian. ${ }^{21}$ Begitu juga dua orang pelajar Cina berumur 22 tahun bernama Tan Yiang Meng dan Chan Wan Leung ditangkap kerana didapati menyimpan buku 
yang diharamkan oleh pihak kerajaan. Mereka didapati menyimpan buku bertajuk Cultivation and Development of Will Power and Personality yang diterbitkan oleh The Youth Publishing Society, China dan buku bertajuk Rudimental Knowledge of Philosophy terbitan Shantung People's Publishing Society. ${ }^{22}$ Di samping itu, seorang gadis Cina bernama Tan Suk Kim telah ditangkap dan dihadapkan ke mahkamah kerana didapati memiliki dokumen komunis. Antara dokumen yang dirampas oleh pihak berkuasa daripadanya adalah dokumen bertajuk "Revolutionary Struggle" dan "To Strive for the Early Liberation of our Mother Country". ${ }^{23} \mathrm{Di}$ sini dapat dilihat komunis turut berusaha untuk menyebarkan pengaruh dan propaganda mereka melalui media cetak kepada penduduk Cina Sarawak. Namun demikian, usaha mereka itu dapat dikesan dan disekat oleh pihak kerajaan.

Salah satu matlamat yang ingin dicapai dalam perjuangan CCO ialah menubuhkan sebuah persekutuan buruh seluruh Sarawak supaya doktrin komunis dapat disebarkan dalam kalangan pekerja dan semua pekerja dapat diletakkan di bawah cengkaman kekuasaannya. Untuk itu, CCO cuba menyatukan semua kesatuan sekerja di Sarawak menerusi kegiatan sekolah malam, bersukan, kumpulan menyanyi dan lain-lain aktiviti khasnya di Kuching dan Sibu. ${ }^{24}$ Antaranya dilaporkan Persatuan Pekerja Pelabuhan (Wharf Workers Unions) di Kuching dan Sibu serta Persekutuan Pertubuhan Pekerja Binaan Kuching adalah terpengaruh dengan komunis. Pada masa itu, hampir semua ahlinya terdiri daripada orang Cina. Sehingga Ogos 1960, komunis telah berjaya mendominasi ahli-ahli jawatankuasa kesatuan sekerja khasnya di Kuching dan Sibu. ${ }^{25}$

Pada Januari 1961, Kongres Kesatuan Sekerja (Trade Union Congress / TUC) di Bahagian Pertama telah didaftarkan dan ia meletakkan asas kepada penglibatan komunis dalam mempengaruhi para pekerja dengan lebih berkesan. Kongres itu mempunyai ahli-ahli yang hampir kesemuanya terdiri daripada orang Cina yang merangkumi gabungan kesatuan-kesatuan sekerja Cina. Manakala dua buah kesatuan sekerja Melayu telah menarik diri daripada kongres itu, iaitu Kesatuan Sekerja Bergaji Hari Jabatan Kerja Raya dan Persatuan Pelaut Kuching. ${ }^{26}$ Pada ketika itu, dianggarkan keanggotaan TUC di Bahagian Pertama adalah seramai lebih kurang 900 orang. Pertubuhan itu penting sebagai "medan" bagi pergerakan komunis untuk mendapat sokongan daripada kalangan pekerja. ${ }^{27}$

Berdasarkan sebuah dokumen komunis yang dirampas oleh pihak kerajaan bahawa rancangan komunis untuk membentuk TUC adalah bertujuan bagi menguasai semua Kesatuan Sekerja dengan menyatukan para pekerja bagi memperjuangkan kepentingan pihak komunis serta menguatkan kegiatan anti-British. Seterusnya komunis bertujuan untuk mewujudkan sebuah negara komunis di Sarawak sebagaimana yang 
berlaku di China yang merupakan objektif utama perjuangan mereka. ${ }^{28}$ Dokumen tersebut juga menekankan bahawa revolusi di Sarawak harus dipimpin oleh kelas pekerja kerana "they have a common destiny, they possess the thorough nature of revolution and the spirit of selflessness." Dokumen komunis lain yang dirampas di Sibu pula menyebut tentang rancangan menjadikan empat kesatuan sekerja sebagai sasaran dalam usaha memperkembangkan kerja revolusinya. Kesatuan yang disebut itu ialah Pertubuhan Pekerja Pelabuhan Sibu, Pertubuhan Pemunggah Kapal Sungai Rajang, Pertubuhan Pemilik Kenderaan Bermotor Sibu dan Kesatuan Pemandu Sibu. ${ }^{29}$

Selain itu, komunis juga menyebarkan pengaruh mereka dengan menyusup masuk ke dalam pertubuhan-pertubuhan peladang di Sarawak. Ini kerana CCO menyedari sokongan daripada golongan itu adalah penting memandangkan 75 peratus daripada penduduk Sarawak adalah peladang atau petani. Daripada itu, satu pertujuh dalam kalangan peladang dan petani di Sarawak adalah kaum Cina. Oleh itu, pada masa yang sama, komunis juga cuba mempengaruhi penduduk Bumiputera (Iban dan Melayu) kepada gerakan komunis. Pihak komunis juga melihat hubungan kaum yang baik wujud antara golongan peladang dan petani dengan penduduk Bumiputera dapat membantu penduduk Bumiputera untuk menyertai gerakan mereka. ${ }^{30}$ Komunis juga berjanji bahawa peladang dan petani tidak akan mengalami penindasan akibat eksploitasi ekonomi oleh tuan tanah sekiranya mereka menyokong komunis. ${ }^{31}$ Bagaimanapun, gerakan komunis gagal mendapat sambutan daripada penduduk Bumiputera di Sarawak. Ini kerana pertama, gerakan komunis di Sarawak lebih bersifat kecinaan dan cenderung memperjuangkan kepentingan orang Cina. Kedua, penduduk Bumiputera sukar untuk memahami fahaman komunis kerana rata-rata mereka mempunyai taraf pendidikan yang rendah. Sebab ketiga, fahaman komunis bertentangan dengan ajaran Islam bagi kalangan penduduk Bumiputera Islam.

Dengan itu, CCO telah memutuskan untuk menubuhkan sebuah barisan yang dikenali Sarawak Farmers' Association (SFA) dan rancangan penubuhannya telah siap pada tahun 1960. Komunis berharap SFA boleh memainkan peranan yang sama seperti TUC untuk golongan pekerja. Bagaimanapun, kerajaan bertindak menolak pendaftaran SFA pada Ogos 1961 kerana pertubuhan itu dipercayai telah digunakan sebagai satelit CCO untuk menyebarkan fahaman dan aktiviti komunis dalam kalangan peladang dan petani di Sarawak. Pada masa yang sama, walaupun pihak SFA menggunakan alasan penubuhannya adalah hendak menjaga kebajikan sosial golongan peladang dan petani melalui gerakan petani/peladang, tetapi cadangan itu telah ditolak oleh kerajaan selepas mendapati antara beberapa orang yang terlibat 
adalah ahli komunis. ${ }^{32}$ Kepentingaan peladang dan pekerja kepada gerakan komunis dapat dilihat melalui sebuah dokumen komunis yang dirampas oleh pihak kerajaan daripada empat orang ahli SFA di Kuching. Dokumen bertajuk "How to Educate the Masses" mencatatkan:

Here is the nature of the revolution of our country: the worker and peasant alliance under the leadership of the working class is the basis of our revolution; this alliance is to join forces with the petty bourgeoisie and national bourgeoisie to form a united front. ${ }^{33}$

Namun demikian, komunis terus menubuhkan sebuah pertubuhan sulit yang dipanggil Pertubuhan Peladang Sarawak pada 18 Jun 1962 dengan tujuan untuk mengkomuniskan golongan peladang dan petani serta memasukkan mereka ke dalam strategi Barisan Bersatu komunis. ${ }^{34}$ Melalui pertubuhan itu juga komunis dapat meletakkan peladang dan petani di bawah pengaruhnya dan menggunakan mereka untuk membesarkan lagi barisan tentera komunis.

Berikutan dengan perkembangan gerakan dan kesedaran politik berparti di Sarawak menjelang proses ke arah berkerajaan sendiri pada lewat tahun 1950-an, CCO juga merancang untuk menggunakan parti politik dalam memperkukuhkan sokongan penduduk. Dengan itu, apabila parti politik pertama, Sarawak United People's Party (SUPP) ditubuhkan pada Jun 1959,35 pihak CCO telah cuba mempengaruhinya. SUPP didominasikan oleh orang Cina dan seringkali dikatakan sebagai parti politik Cina yang pertama di Sarawak. Pembentukan parti ini telah membuka ruang kepada ahli-ahli komunis untuk menggunakannya sebagai "alat" politik dalam usaha menyebarkan pengaruh mereka dalam kalangan orang Cina Sarawak.

Menurut CCO, parti SUPP perlu disokong kerana pertubuhan ini berjuang untuk mengusir penjajah British dan mendapatkan kemerdekaan bagi Sarawak dan seterusnya dapat membentuk sebuah republik komunis. SUPP juga disokong kerana komunis berhasrat menjadikan parti itu sebagai asas pembangunan kerja-kerja subversifnya. Di samping itu, komunis juga mahu menguasai barisan pucuk pimpinan SUPP supaya semua pergerakan massa diletakkan di bawah pengaruh dan kekuasaannya. ${ }^{36}$ Kepentingan parti politik dalam perjuangan komunis di Sarawak dinyatakan dalam sebuah dokumen komunis yang dirampas oleh pihak kerajaan. Dokumen bertajuk "On the Formation of an Open Political Party and the Struggle for Independence" yang disebarkan pada awal tahun 1959 telah menjelaskan bahawa parti politik merupakan satu cara yang berkesan untuk meneruskan dan mempergiatkan gerakan komunis di Sarawak. ${ }^{37}$ 
Pengaruh komunis dalam SUPP dapat dilihat melalui penangkapan empat orang Cina Sarawak pada 23 Julai 1962 oleh kerajaan. Mereka mengambil bahagian dalam kegiatan CCO dan ditangkap oleh kerajaan Sarawak di bawah Ordinan Sekatan Kediaman. Mereka ialah Tan Kheng Aik dan Lui How Ming, editor akhbar Min Chong Pao (Sibu) serta Sa Min Pao (Miri); Teo Yung Kiaw dan Tin Man Wo (juga dikenali Chan Boon Ho) adalah pemimpin kesatuan sekerja. Pada masa yang sama, mereka didapati juga adalah ahli jawatankuasa SUPP. ${ }^{38}$ Pengaruh komunis dalam SUPP juga dapat dilihat melalui enam orang yang telah ditangkap di Batu 17 Jalan Serian-Simanggang pada pagi 5 Januari 1963. Mereka dipercayai ahli CCO yang aktif dan penting serta pada masa yang sama juga adalah ahli SUPP. ${ }^{39}$ Begitu juga, dengan penangkapan 69 orang belia Cina di kawasan sempadan Sarawak dengan Indonesia yang dipercayai cuba menyeberangi sempadan untuk mendapat latihan ketenteraan di Indonesia bagi melanjutkan kegiatan komunis di Sarawak. Antara mereka yang ditangkap itu, lebih daripada 20 orang memiliki lencana SUPP. ${ }^{40}$

Berdasarkan sebuah dokumen yang dirampas oleh pihak kerajaan daripada Pertubuhan Sulit Komunis menunjukkan pihak komunis memang menyokong SUPP dan ingin menggunakannya sebagai landasan untuk mencapai cita-cita politik mereka di Sarawak supaya dapat menyembunyikan perjuangan mereka yang sebenarnya dari pengetahuan pihak kerajaan. Dasar komunis ialah menyokong SUPP dan cuba menyatukan kelas berharta iaitu pemimpin SUPP dengan ahli-ahli komunis. Oleh itu, CCO harus mengekalkan hubungan persahabatan dengan mereka yang berharta supaya memudahkan komunis memperalatkan SUPP untuk menjalankan kerja revolusi. ${ }^{41}$ Dengan itu, boleh dikatakan pihak komunis menyokong SUPP dengan tujuan tertentu dan bukan untuk memberi sokongan sepenuh kepada SUPP sebagaimana yang dicatatkan dalam sebuah dokumen berbunyi "Make use of it when it is useful and attack it when it becomes useless". ${ }^{42}$

Dengan itu, terdapat penglibatan mereka yang pro-komunis dalam Jawatankuasa Pusat SUPP. Antaranya, Wen Ming Chyuan pernah dilantik sebagai Setiausaha Propaganda Pendidikan dalam Jawatankuasa Pusat SUPP 1960-1962 dan seterusnya Wen Ming Chyuan serta Bong Kee Chok dilantik sebagai Timbalan Setiausaha Umum SUPP dalam barisan ahli Jawatankuasa Pusat SUPP pada 1962-1964. Selain itu, Lui How Ming, iaitu abang kepada isteri Bong Kee Chok, Lui How Ing juga adalah anggota SUPP. Bagaimanapun, pada Jun 1962, Wen Ming Chyuan dan isterinya Wong Fuk Ing, Bong Kee Chok dan isterinya Lui How Ing bersama dengan Chin Shao Thong dan Lin Yonglin telah ditahan. Wen Ming Chyuan dan Bong Kee Chok telah memilih pulang ke China tetapi mereka kemudian telah masuk ke Kalimantan 
Barat pada Mac-April 1963 dan bersembunyi di sana sebelum kembali ke Sarawak. Di sana juga pemimpin komunis itu telah menghadiri beberapa perjumpaan dan perbincangan dengan komunis Indonesia di Jakarta dan Pontianak. ${ }^{43}$

Selain itu, CCO juga merekrut wanita Cina muda untuk dijadikan pembawa utusan komunis dan tugas lain. Dua orang wanita Cina telah dihadap ke mahkamah kerana didapati memiliki dokumen komunis. Kedua-duanya mempunyai latar belakang pendidikan sekolah Cina, ahli kesatuan sekerja dan pada masa yang sama juga menjadi anggota SUPP. Wanita pertama ialah seorang Cina Hakka dari Kuching, berumur 23 tahun dan berkelulusan dari sekolah Cina di Kuching, seorang ahli Kesatuan Buruh dan Pekerja Kuching serta menjadi ahli SUPP. Manakala seorang lagi ialah seorang wanita Cina Teochew yang berumur 24 tahun dari Kuching. Beliau berkelulusan sekolah Cina, bekerja di sebuah akhbar Cina, iaitu Sin Wen Pao di Kuching dan juga menjadi ahli jawatankuasa Kesatuan Pekerja Percetakan Kuching serta ahli SUPP. ${ }^{44}$ Dengan itu, jelas bahawa selain lelaki Cina adalah penting dalam pergerakan komunis, golongan wanita yang berpendidikan Cina juga digunakan oleh komunis dalam membantu kerja-kerja propaganda.

Dengan itu, jelaslah menunjukkan pihak komunis memang berusaha bersungguh-sungguh untuk menyebarkan fahaman dan pengaruh komunis dalam kalangan masyarakat Cina dengan cuba mengambil semua saluran supaya fahaman komunis dapat dikembangkan dan cita-cita politik mereka menjadi realiti. Gerakan komunis sebelum tahun 1963 lebih tertumpu kepada cara dan strategi untuk menyebarkan fahaman dan pengaruh kepada kalangan penduduk supaya dapat menguatkan barisan tentera dan penyokongnya. Dengan itu, komunis di bawah CCO telah menyusup ke dalam sekolah, pertubuhan, kesatuan sekerja, parti politik dan menggunakan media sebagai saluran untuk menyebarluaskan pengaruh mereka dan sekaligus meletakkan pertubuhan itu di bawah kekuasaannya. Kerajaan tidak membiarkan keadaan itu berterusan dan langkah telah diambil untuk menyekat sekolah, pertubuhan, kesatuan sekerja, parti politik dan media daripada disalahgunakan oleh komunis. Justeru itu, komunis hanya memperoleh sedikit pencapaian dalam gerakan mereka. Namun demikian, mereka tidak berputus asa dan masih terus bergerak di Sarawak.

\section{Orang Cina dan Pergerakan Komunis, 1963-1974}

Selepas rancangan Malaysia diumumkan oleh Tunku Abdul Rahman dan akhirnya Persekutuan Malaysia dibentuk pada 16 September 1963, komunis masih meneruskan gerakannya di Sarawak. Dalam perkembangan itu, komunis menunjukkan tentangan terhadap 
rancangan Malaysia. Ini kerana bagi pihak komunis, penubuhan Malaysia adalah satu ancaman dan halangan untuk mereka mencapai matlamat perjuangannya. Berikutan itu, komunis memulakan penentangan dan serangan dalam usaha untuk menggagalkan Persekutuan Malaysia. Untuk mengawal keadaan di Sarawak, kerajaan telah melancarkan penangkapan pelajar, pekerja, petani dan golongan kiri dalam SUPP. Tindakan kerajaan itu telah menimbulkan rasa tidak puas penduduk.

Menjelang pembentukan Persekutuan Malaysia, Parti Rakyat Brunei (PRB) di bawah A.M. Azahari Mahmud melakukan pemberontakan untuk merampas kuasa di Brunei. PRB juga bertujuan untuk menyatukan Sarawak bersama Sabah dan Brunei bagi membentuk Negara Kalimantan Utara. Dengan itu, A.M. Azahari menentang pembentukan Malaysia yang boleh menyekat rancangan penguasaannya ke atas wilayah Borneo. Ekorannya, komunis Sarawak membina hubungan dengan Tentera Nasional Kalimantan Utara (TNKU), unit tentera PRB yang ditubuhkan untuk menentang pembentukan Malaysia. TNKU turut mendapat sokongan terbuka di Indonesia yang juga tidak setuju dengan rancangan Malaysia. Bagi pihak Indonesia pula, pembentukan Malaysia adalah satu bentuk penjajahan baru dan bukan pembebasan Sabah dan Sarawak daripada penjajahan. Justeru itu, komunis telah memberi sokongan kepada perjuangan A.M. Azahari di Brunei dan kemudian Konfrontasi Indonesia terhadap Malaysia.

Apabila Persekutuan Malaysia ditubuhkan pada 16 September 1963, komunis di bawah pimpinan Bong Kee Chok telah memulakan gerakan bersenjata. Unit-unit tentera komunis pun bergerak di seluruh Sarawak. Pada peringkat itu, orang Cina masih tidak dapat dipisahkan dengan gerakan komunis. Orang Cina masih menjadi tumpuan utama komunis untuk mempengaruhinya supaya mereka menyokong perjuangan komunis di Sarawak ke arah mencapai cita-cita komunis menguasai Sarawak. Pihak kerajaan mendapati ramai komunis Cina Sarawak telah melintasi sempadan dan masuk ke Kalimantan Indonesia untuk mendapat latihan ketenteraan sebagai persediaan untuk mereka melancarkan gerakan anti-Malaysia bersama komunis Indonesia. Untuk itu, pada Jun 1964, kerajaan Sarawak telah mendapati lebih kurang 1,000 orang belia Cina Sarawak telah pergi ke Kalimantan bagi mendapatkan latihan ketenteraan di sana. ${ }^{45}$

Ketika Konfrontasi Indonesia berlaku, aktiviti komunis tertumpu di kawasan sempadan Kalimantan-Sarawak. Komunis dihantar ke Indonesia untuk mendapatkan latihan ketenteraan dan kemudian menyusup masuk ke kawasan Sarawak. Mereka melakukan serangan dan bertempur dengan pihak keselamatan sehingga membawa kepada kematian dan kecederaan. Dalam kejadian yang berlaku itu, 
terdapat penglibatan komunis Sarawak bersama dengan komunis Indonesia. Antaranya, kerajaan mendapati dalam kumpulan komunis yang menyusup masuk dari Indonesia ke dearah Lundu, sekurungkurangnya 19 orang adalah orang Cina Sarawak yang mendapat latihan ketenteraan di Kalimantan Barat pada tahun 1964. Mereka itu telah diberi bantuan makanan oleh orang Cina tempatan yang tinggal di kawasan sempadan. ${ }^{46}$ Kekacauan banyak berlaku di kawasan sempadan, antaranya di kawasan Jambu dan Lubok Antu di Bahagian Kedua, daerah Serian, Lundu, Serikin, Tebedu, Kandai, Tepoi dan Plaman Mapu di Bahagian Pertama Sarawak. ${ }^{47}$

Pada 27 Jun 1965, Balai Polis Batu 18 Jalan Kuching-Serian telah diserang oleh sekumpulan komunis. Kerajaan mendapati kumpulan komunis Indonesia itu mendapat bantuan daripada komunis Cina Sarawak dan orang Cina yang bersimpati dengan mereka. Dalam kejadian itu, dua orang polis terkorban termasuk adik kepada Ketua Menteri Sarawak ketika itu dan lapan orang awam terbunuh serta beberapa orang lagi cedera. ${ }^{48}$ Penglibatan orang Cina dalam kejadian komunis itu telah menimbulkan persoalan tentang kesetiaan orang Cina Sarawak terhadap Persekutuan Malaysia. Guardian, 8 July 1965 menuliskan "... that crime, was possible only through the help of resident Chinese Communists or Communist sympathisers. The loyalty of many Sarawak Chinese to the new federation of Malaysia has long been suspect." 49 Dengan itu, adalah jelas bahawa gerakan komunis di Sarawak adalah berkait rapat dengan orang Cina sehingga menimbulkan keraguan pihak kerajaan terhadap kesetiaan orang Cina ke atas Sarawak.

Bagaimanapun, berikutan kejadian komunis menyerang Balai Polis Batu 18 Jalan Kuching-Serian, kerajaan telah melancarkan "Operation Hammer" pada 6 Julai 1965 untuk mengumpulkan semula orang Cina yang tinggal di kawasan Batu 15 hingga Batu 24 di Jalan Kuching-Serian di Bahagian Pertama Sarawak dan ditempatkan semula di tiga buah kampung baru, iaitu Siburan, Beratok dan Tapah. Tujuannya adalah untuk membolehkan pihak kerajaan menghapuskan kegiatan subversif komunis dalam kalangan penduduk Cina dan menghalang komunis mendapatkan bantuan makanan dan keperluan daripada penduduk. ${ }^{50}$ Pasukan keselamatan turut menjumpai sejumlah senjata di kawasan berkenaan. Pihak kerajaan juga megadakan siasatan ke atas laluan Sungai Sadong yang digunakan oleh penyerang melarikan diri. ${ }^{51}$

Di bawah operasi itu, lebih 8,000 orang penduduk Cina daripada 1,285 keluarga yang terlibat dan 41 orang Cina pula ditahan oleh Cawangan Khas kerana disyaki adalah komunis atau membantu komunis. Mereka merupakan petani yang mengusahakan tanaman lada hitam, getah dan sayur. Di bawah "Operation Hammer", kerajaan turut melancarkan "Operation Letterbox" pada 23 Julai 
1965 untuk memperoleh maklumat tentang pergerakan komunis daripada penduduk. Seramai 2,000 daripada 8,000 penduduk di pusat penempatan itu telah diberi kertas soal selidik bagi mendapatkan maklumat tentang kegiatan komunis di kawasan mereka. Penduduk diminta memasukkan kertas soal selidik yang telah diisi ke dalam petipeti undi yang disediakan. ${ }^{52}$

Pada 16 Februari 1966, pihak kerajaan dapat mengesan sekumpulan 50 hingga 60 orang bersenjata melintasi sempadan Indonesia masuk ke Bahagian Pertama dan Kedua Sarawak. Setelah siasatan dilakukan didapati serama 26 orang daripadanya berhubung dengan penduduk di kawasan penempatan semula Jalan Kuching-Serian di bawah "Operation Hammer" bagi mendapatkan makanan dan simpati. Ekorannya, kerajaan mengenakan tiga hari perintah berkurung bermula 22 Februari untuk membolehkan pasukan keselamatan menjalankan siasatan lanjutan ke atas kawasan itu. Beberapa orang Cina dari kampung baru itu telah ditahan oleh pihak kerajaan dan senjata api mereka dijumpai disembunyikan dalam hutan berdekatan. Daripada itu juga didapati sebahagian daripada senjata api itu adalah senjata yang dirampas dari Balai Polis Batu 18 ketika serangan komunis pada Julai 1965. Akhirnya, salah seorang daripada orang Cina yang ditahan itu didapati telah mengambil bahagian dalam kejadian serangan ke atas Balai Polis Batu 18.53

Jelas dalam pergerakan komunis, sokongan orang ramai khasnya orang Cina adalah penting. Keadaan itu turut disedari oleh CCO. Daripada laporan kerajaan bertajuk "Report of The Committee on Regrouping and Resettlement in Borneo", didapati komunis berusaha untuk mempergunakan golongan Cina pertengahan di kawasan Jalan Kuching-Serian dan mereka telah direkrut sebagai pengantar utusan komunis (couriers). Komunis juga meletakkan orang yang menyokong gerakan mereka sebagai guru di sekolah rendah Cina. Mereka juga mengadakan kelas malam dan menyusun pasukan bola keranjang dalam rancangan untuk mendoktrinasikan orang Cina tempatan. ${ }^{54}$ Walaupun pergerakan komunis pada tahun 1960-an tidak dapat dipisahkan dengan orang Cina, namun pada masa yang sama CCO juga berusaha untuk mendapatkan sokongan penduduk pribumi Sarawak. Ini selaras dengan arahan kerja CCO yang menggariskan tugas utama barisan bawah tanah dengan objektif komunis sebagaimana yang dinyatakan dalam Kertas Putih kerajaan bertajuk The Threat of Armed Communism in Sarawak. Barisan bawah tanah komunis adalah seperti SFA, Self-Protection Corps (SPC) dan Hsueh Hsih cells serta Kalimantan National Liberation League (NKNLL). Antara tugas dan objektif yang ingin dicapai oleh CCO melalui barisan bawah tanah adalah: 
If we can gain the support of the native masses, we will be able to settle down, carry out work to win the masses extensively, carry out guerilla struggle, and gradually work for the establishment of bases ...

In the Chinese areas ... we should intensify the execution of overall policy ... Our overall strength and intensifying struggle in the various fields ... In the course of close liaison with the masses, comrades and cadres will gain new recruits ...

In short, to intensify close liaison with the masses is the most important task for further development of the revolution and armed struggle at present..$^{55}$

Dalam pergerakan komunis selepas pembentukan Malaysia, SUPP masih dikaitkan dengan pengaruh komunis yang dikatakan berterusan dalam parti. Ini kerana SUPP merupakan parti yang dikuasai oleh orang Cina dan adalah parti pembangkang dalam kerajaan Sarawak sehingga tahun 1970. Semasa gagasan Malaysia diumumkan, SUPP bertindak membantah cadangan Tunku Abdul Rahman yang melibatkan percantuman Tanah Melayu, Singapura, Brunei, Sarawak dan Borneo Utara sebagai satu unit politik. SUPP menganggap gagasan Malaysia akan merugikan mereka kerana pemerintahan kerajaan di Tanah Melayu didominasi oleh orang Melayu. Ini bermakna SUPP bimbang bahawa Sarawak akan dikuasai oleh Tanah Melayu. Dalam pada itu, SUPP berpendapat Sarawak harus diberi kemerdekaan sepenuh sebelum mempertimbangkan penyatuan dengan unit politik yang lain. Malahan selepas Sarawak mencapai kemerdekaan melalui Persekutuan Malaysia pada 16 September 1963, SUPP masih menjadi parti pembangkang dalam arena politik Sarawak. ${ }^{56}$

Dengan itu, komunis melihat SUPP sebagai saluran yang boleh mereka mempengaruhinya untuk membantu pergerakan komunis dalam kalangan orang Cina di Sarawak. Memandangkan keadaan itu, kerajaan telah mengambil tindakan untuk mengawal kegiatan komunis dalam SUPP. Pada 13 Mei 1964, cawangan dan ranting SUPP di Lundu telah diarahkan ditutup oleh kerajaan kerana dikatakan telah dijadikan alat oleh komunis untuk kegiatan menyebarkan propaganda komunis dan memberi sokongan langsung kepada gerila Indonesia. Berikutnya pada September 1965, cawangan SUPP di Sarikei dan Jakar telah diarahkan ditutup dengan alasan yang sama. ${ }^{57}$

Selain SUPP, kerajaan juga mendapati satu pertiga daripada Kesatuan Sekerja di Sarawak adalah masih di bawah pengaruh komunis selepas Sarawak mencapai kemerdekaan. Begitu juga sesetengah sekolah rendah dan menengah Cina juga dikesani masih dipengaruhi komunis. Penyebaran gerakan komunis turut dilakukan melalui buku, terbitan berkala dan terbitan berunsur subversif yang sama ada berasal dari China atau diterbitkan semula di tempatan. ${ }^{58}$ Dengan itu, adalah 
jelas bahawa orang Cina di Sarawak masih tidak dapat dipisahkan dengan pergerakan komunis selepas kemerdekaan.

Pada tahun 1970-an, misalnya, pihak Cawangan Khas telah mendapati banyak pertubuhan dan kesatuan sekerja di Bahagian Ketiga Sarawak adalah dipengaruhi oleh komunis. Hampir kesemua yang terlibat adalah pertubuhan yang didominasikan oleh orang Cina. Antaranya, Sarikei Hire Motor Vehicle Drivers' Union dan Sarikei Foochow Association telah dikuasai oleh komunis. Manakala, Binatang Wharf Labourers' Union, Sibu Poultry \& Pig Rearers' Association dan Sibu Foochow Association pula adalah pro-komunis. Di samping itu, beberapa buah lagi pertubuhan dan kesatuan sekerja juga diresapi komunis termasuk Lower Sg. Baji Ferry \& Road Association di Sarikei, Pei Hoo Physical Association (Sarikei), Su Lee Ferry \& Path Association (Sarikei), Sibu Lorry Association, Sibu Construction Workers' Association, Sibu Dockyard Workers' Union, Sibu Carpentry Workers' Union, Sibu Coffee-Shop Employees' Union, Sibu Wharf E Port Labourers' Union, Mukah Wharf Labourers' Union dan Mukah Basketball Association. ${ }^{59}$

Dengan itu, dapat dilihat bahawa selepas merdeka, gerakan komunis di Sarawak masih bergantung kepada beberapa organisasi dalam meluaskan pengaruh serta kegiatannya. Pertubuhan bawah tanah iaitu SFA dan SPC yang menumpukan kegiatan mengindoktrinasikan dan menyusun kader-kader komunis di kawasan luar bandar dan terpencil bagi melancarkan gerakan bersenjata. Manakala, pada masa yang sama, CCO juga berusaha untuk mempengaruhi dan menggunakan SUPP dalam perjuangan politik terbuka di Sarawak dengan kerajaan dengan kawasan tumpuannya di kawasan bandar.

Seterusnya, CCO mengambil keputusan untuk menyusun semula gerakannya untuk membolehkan mereka memperkukuhkan kegiatan di Sarawak. CCO membangkitkan cadangan pembentukan sebuah parti komunis bersama komunis Indonesia. Dengan itu, satu perbincangan rahsia telah diadakan di antara CCO dan Parti Komunis Indonesia (PKI) pada 17-19 September 1965 di Pontianak, Kalimantan Barat. Penubuhan parti yang dinamakan sebagai Parti Komunis Kalimantan Utara (PKKU) atau North Kalimantan Communist Party (NKCP) telah diumumkan oleh Lim Ho Kui (Lam Wah Kwai) di Teluk Sabang, Nonok, Sarawak dan kemudian oleh Bong Kee Chok pada 30 Mac 1970. Penubuhan PKKU seterusnya diluluskan oleh Jawatankuasa Pusat CCO dan pengumuman rasmi penubuhan parti itu dilakukan oleh Bong Kee Chok pada 19 September 1971. Namun demikian, terdapat sumber yang mencatatkan tarikh penubuhan PKKU ialah 30 Mac 1970 seperti dalam Kertas Putih Kerajaan bertajuk "The Threat of Armed Communism in Sarawak" yang diterbitkan pada tahun $1972 .{ }^{60}$ PKKU mempunyai dua unit tentera yang dikenali sebagai Pasukan Rakyat Kalimantan Utara (PARAKU) 
dan Pasukan Gerila Rakyat Sarawak (PGRS). PARAKU bergerak di bahagian timur Sarawak dan PGRS di bahagian barat. PARAKU diketuai oleh Bong Kee Chok dan Hung Chun Ting. Cawangan ketiga PGRS diketuai oleh Yap Choon Ho dan Yang Zhu Zhong. Cawangan lain PGRS dipimpin oleh Lin He Gui alias Lin Yan Hua dan Bong Han. ${ }^{61}$

Apabila berhadapan dengan tekanan hebat daripada pihak kerajaan dan pasukan keselamatan di Bahagian Pertama Sarawak, gerila komunis mula beralih ke Bahagian Ketiga yang terletak jauh daripada pusat pentadbiran, Kuching. Dengan itu, gerakan komunis di Bahagian Ketiga semakin aktif di bawah Biro Kedua PKKU yang dibahagikan kepada 120 unit dan dibantu oleh hampir 4,000 orang penyokong. ${ }^{62}$ Perkembangan gerakan komunis itu telah membimbangkan pihak kerajaan. Memandangkan keadaan itu, Bahagian Ketiga telah diisytiharkan oleh Perdana Menteri Malaysia, Tun Abdul Razak sebagai Kawasan Keselamatan Khas (Special Security Area) atau Rajang Area Security Command (RASCOM) pada 26 Mac 1972 bagi mempercepatkan langkah membasmi komunis di bahagian itu. ${ }^{63}$ Seiring itu, sebuah pasukan RASCOM telah ditubuhkan yang dianggotai oleh gabungan pasukan polis, tentera dan penjawat awam bertujuan untuk memastikan operasi-operasi menentang komunis di kawasan Rejang dirancang dan diarahkan dengan berkesan. ${ }^{64}$ Kawasan tumpuan gerakan komunis di kawasan RASCOM adalah Sibu, Mukah, Kanowit, Sarikei, Binatang (dikenali Bintangor pada hari ini) dan Julau. Pemimpin komunis utama di kawasan RASCOM di Bahagian Ketiga Sarawak ialah Hung Chu Ting. ${ }^{65}$ Beliau mengetuai HQ Central Command Unit bagi Biro Kedua PKKU di Bahagian Ketiga Sarawak dan dibantu oleh beberapa pemimpin penting iaitu Wong Lian Kui, Wong Siong Hoon, Yong Wai Keong, Ling Kee Ching dan Wong Lee Heng. ${ }^{66}$

Berikutan operasi ketenteraan yang dilakukan oleh kerajaan dan pasukan tentera Sarawak/Malaysia serta Indonesia, komunis menghadapi banyak kesukaran dalam gerakan mereka. Mereka menghadapi kekurangan bekalan makanan, ubat-ubatan, kelengkapan senjata dan lebih-lebih lagi apabila 51 orang anggotanya ditawan oleh pihak keselamatan pada tahun 1973. Keadaan itu telah memberi tamparan hebat kepada semangat juang komunis. Pada masa yang sama pula, penduduk tidak lagi membantu komunis, sebaliknya mereka bekerjasama dengan kerajaan yang telah membawa banyak pembangunan sosioekonomi Sarawak. Di bawah pimpinan Abdul Rahman Yaakub, projek pembangunan ekonomi, pelaburan asing, industri minyak dan gas, projek hidroeletrik, industri pembalakan dan pembangunan tanah telah berkembang dengan pesat. ${ }^{67}$ Memandangkan perkembangan itu, Bong Kee Chok dan beberapa orang rakannya cuba mencari jalan untuk menguatkan barisan gerila komunis supaya mereka 
dapat meneruskan kegiatan dan serangan di Sarawak. Berikutnya, Bong Kee Chok telah meninggalkan Bahagian Ketiga Sarawak dan pergi ke Bahagian Pertama untuk bertemu dengan pemimpin komunis yang lain. Mereka telah cuba membincang dan merancang untuk bekerjasama dengan North Kalimantan Liberation Army. Namun rancangan mereka tidak berjaya dan itu membawa kepada Bong Kee Chok memikirkan semula masa depan perjuangan bersenjata komunis di Sarawak. ${ }^{68}$

Akhirnya, sebahagian besar gerila komunis yang sedar tentang perjuangan mereka selama ini adalah sia-sia sahaja telah bersetuju untuk menghentikan perjuangan dan kembali semula kepada masyarakat. Justeru itu, Bong Kee Chok mengutus surat kepada Ketua Menteri Sarawak selaku Pengarah Gerakan Negeri. Dalam surat bertarikh 10 Oktober $1973 \mathrm{itu}$, Bong Kee Chok menyatakan kesediaan untuk berbincang bagi menghentikan perjuangan komunis dan memulihkan keamanan serta kestabilan negara. Berikutnya, satu rundingan diadakan pada 19-21 Oktober 1973 dan pihak komunis bersetuju untuk menandatangani satu perjanjian Memorandum Persefahaman dengan kerajaan Sarawak pada 21 Oktober. Pihak komunis diwakili oleh pengasas CCO yang juga adalah Pengarah dan Komisar Politik PARAKU, Bong Kee Chok dengan Ketua Menteri dan selaku Pengarah Gerakan Negeri Sarawak, Abdul Rahman Yaakub di Rumah Kerajaan di Simanggang. ${ }^{69}$

Seterusnya, pada 4 Mac 1974, kerajaan melancarkan Operasi Sri Aman. Operasi itu dilancarkan sehingga 4 Julai 1974 untuk membolehkan gerila komunis keluar dari tempat persembunyian dengan selamat. Operasi itu telah membawa kepada penyerahan diri komunis secara beramai-ramai termasuklah Bong Kee Chok kepada pihak kerajaan. Sehingga tamatnya tempoh penyerahan yang ditetapkan pada 4 Julai 1974, dilaporkan lebih 500 orang gerila komunis telah bersetuju menyerah diri dan meletak senjata. Penyerahan itu telah berjaya mengurangkan sebanyak 85 peratus jumlah kekuatan komunis di Sarawak. ${ }^{70}$ Kejayaan Operasi Sri Aman telah menjejaskan kekuatan gerakan komunis dan hampir melumpuhkannya. Sebaliknya, pencapaian yang cemerlang dalam Operasi Ari Aman merupakan satu kejayaan yang dicapai oleh kerajaan dan membawa satu lembaran baru dalam usaha kerajaan menentang komunis di Sarawak.

Walaupun kekuatan komunis telah semakin terjejas berikutan penyerahan diri beramai-ramai gerila komunis di bawah Operasi Sri Aman, tetapi masih terdapat gerila komunis yang ingin meneruskan perjuangan mereka di Sarawak. Bagaimanapun, gerakan mereka semakin sukar kerana berdepan dengan pelbagai masalah seperti tekanan daripada pasukan keselamatan, kekurangan bekalan makanan 
dan kelengkapan ketenteraan serta bantuan daripada penyokong. Pada masa yang sama, pihak kerajaan dan anggota keselamatan masih meneruskan gerakan ketenteraan untuk menghapuskan saki baki komunis yang masih berjuang dalam hutan sehingga tahun 1990. Pada 17 Oktober 1990, di Wisma Bapa Sarawak, Kuching, satu perjanjian damai yang mengakhiri insurgensi komunis di Sarawak ditandatangani di antara PKKU dengan kerajaan Sarawak. ${ }^{71}$

\section{Kesimpulan}

Perbincangan di atas, jelas menunjukkan bahawa Sarawak berdepan dengan bahaya ancaman komunis yang cuba menyebarkan fahamannya. Dalam gerakan komunis, hampir kesemua daripada mereka yang terlibat adalah orang Cina. Orang Cina merupakan golongan terbesar yang bersimpati dengan perjuangan komunis. Lantaran itu, mereka dijadikan alat untuk menyebarkan fahaman komunis dan bagi mendapatkan sokongan demi menjayakan cita-cita politik komunis di Sarawak. Lebih-lebih lagi orang Cina pada ketika itu rata-ratanya menjalin hubungan yang rapat dengan China dan pengaruh komunis di Sarawak juga disebarkan dari China. Golongan tersebut mudah terpengaruh dan dipengaruhi oleh fahaman komunis yang disebarkan dari China oleh orang Cina melalui sekolah Cina, akhbar Cina dan terbitan, kesatuan sekerja dan peladang serta pertubuhan politik. Dengan itu, secara umumnya, perkembangan komunis di Sarawak lebih bersifat keCinaan dan orang Cina menjadi tulang belakang serta aset utama bagi gerakan komunis baik sebelum mahupun selepas merdeka.

Penyebaran fahaman komunis dalam kalangan orang Cina dan penglibatan mereka secara langsung atau tidak langsung dalam gerakan komunis itu telah membimbangkan pihak kerajaan. Ini kerana orang Cina adalah golongan yang penting khasnya dalam pembangunan ekonomi Sarawak dan mereka juga membentuk kumpulan penduduk yang kedua terbesar di Sarawak. Memandangkan itu, kerajaan telah menjalankan pelbagai langkah untuk menyekat gerakan komunis daripada terus berkembang di Sarawak seperti pelacaran operasi ketenteraan dan mengawal aktiviti percetakan akhbar, sekolah Cina, pertubuhan dan pemilikan senjata api. Kerajaan juga mengambil langkah untuk menjauhkan penduduk daripada gerakan komunis dengan menjalankan rancangan pengumpulan dan penempatan semula penduduk. Bagaimanapun, permasalahan komunis di Sarawak mula reda berikutan kejayaan pelancaran Operasi Sri Aman pada tahun 1974 oleh kerajaan. 


\section{Nota}

1 Monthly Review of Chinese Affairs, August 1934, CO 273/597/33046/ III, Review of Chinese Affairs. Lihat juga Ho Hui Ling, Pembanterasan Komunis di Tanah Melayu, Kuala Lumpur: Penerbit Universiti Malaya, 2010, hlm. 2-3.

2 Mohd. Reduan Haji Asli, Pemberontakan Bersenjata Komunis di Malaysia, Kuala Lumpur: Dewan Bahasa dan Pustaka, 1993, hlm. 74.

3 Chin Ung-Ho, Chinese Politics in Sarawak: A Study of the Sarawak United People's Party, Kuala Lumpur: Oxford University Press, 1996, hlm. 40; Craig A. Lockard, From Kampung To City: A Social History of Kuching Malaysia 1820-1970, Athens: Ohio University, 1987, hlm. 168-169; Ho Hui Ling, "Kegiatan Clandestine Communist Organisation (CCO) di Sarawak, 19501963: Satu Tinjauan Umum", Sejarah, Jurnal Jabatan Sejarah Universiti Malaya, No. 7, 1999, hlm. 184.

4 Vernon L. Porritt, The Rise and Fall of Communism in Sarawak, 1940-1990, Victoria, Australia: Monash University Press, 2004, hlm. 7; Fujio Hara, "The North Kalimantan Communist Party and The People's Republic of China", The Developing Economics, Vol. XLIII, No. 4, December 2005, hlm. 490. Lihat juga Justus M. Van Der Kroef, "Communism in Sarawak Today", Asian Survey, Vol. 6, No. 10, 1966, hlm. 570.

5 The Borneo Post, 16 September 2011. Lihat juga Hara Fujio, "The North Kalimantan Communist Party: Preliminary Study", Michael Leigh (ed.), Borneo 2000: Proceedings of the Sixth Biennial Borneo Research Conference, Kuching, Sarawak, 10-14 July 2000, hlm. 199; The Communist Threat To Sarawak, Kuala Lumpur: Jabatan Chetak Kerajaan, 1966, hlm. 1.

6 Ho Hui Ling, "Kegiatan Clandestine Communist Organisation (CCO) di Sarawak, 1950-1963: Satu Tinjauan Umum", hlm. 185; F.W. Goodwin, Sarawak Council Negri, Subversion in Sarawak, Kuching: Government Printing Office, 1960, hlm. 1. Lihat juga Michael B. Leigh, The Chinese Community of Sarawak, Singapore: University of Singapore, 1964, hlm. 50; Vernon L. Porritt, British Colonial Rule in Sarawak, 1946-1963, Kuala Lumpur: Oxford University Press, 1997, hlm. 77; Mohd. Reduan Haji Asli, Pemberontakan Bersenjata Komunis di Malaysia, hlm. 74-75; Justus M. Van Der Kroef, "Communism and Chinese Communalism in Sarawak", The China Quarterly, No. 20, Oct.-Dec. 1964, hlm. 39; North Borneo News and Sabah Times, 15 March 1963, hlm. 2.

7 Mohd. Reduan Haji Asli, Pemberontakan Bersenjata Komunis di Malaysia, hlm. 75; The Communist Threat To Sarawak, hlm. 2.

8 Mohd. Reduan Haji Asli, Pemberontakan Bersenjata Komunis di Malaysia, hlm. 76. Lihat juga Justus M. Van Der Kroef, "Communism and Chinese Communalism in Sarawak", hlm. 39.

9 The Communist Threat To Sarawak, Kuala Lumpur: Jabatan Chetak Kerajaan, 1966, hlm. 2.

$10 \quad$ F.W. Goodwin, Sarawak Council Negri, Subversion in Sarawak, hlm. 2.

11 DO 187/69, Report of The Communist Threat \& Local Chinese Problems in Sarawak \& Sabah with Recommendations, by Head, Psychological 
Warfare Section, Ministry of Internal Security, Government of Malaysia, December 1963, Kuala Lumpur.

Ibid.

Utusan Sarawak, 28 July 1960, hlm. 2.

The Borneo Bulletin, 26 September 1959, hlm. 8.

Ibid.

F.W. Goodwin, Sarawak Council Negri, Subversion in Sarawak, hlm. 2.

Vernon L. Porritt, The Rise and Fall of Communism in Sarawak 1940-1990,

hlm. 10-11. Lihat juga The Sarawak Tribune, 30 October 1951, hlm. 1; 1

December 1951, hlm. 1; 14 February 1952, hlm. 1; The Sarawak Gazette, 31 December 1952, hlm. 276.

John M. Chin, The Sarawak Chinese, Kuala Lumpur: Oxford University Press, 1981, hlm. 107-109; Vernon L. Porritt, The Rise and Fall of Communism in Sarawak 1940-1990, hlm. 8-9; Sarawak By The Week, 26 November-2 December 1961, hlm. 2.

Chin Ung-Ho, Chinese Politics in Sarawak, hlm. 44; John M. Chin, The Sarawak Chinese, hlm. 107-109.

Mohd. Reduan Haji Asli, Pemberontakan Bersenjata Komunis di Malaysia, hlm. 84; Justus M. Van Der Kroef, "Communism and Chinese Communalism in Sarawak", hlm. 40-41.

Utusan Sarawak, 18 August 1960, hlm. 1.

The Borneo Bulletin, 26 September 1959, hlm. 8-9.

Daily Express, 4 July 1963, hlm. 7.

F.W. Goodwin, Sarawak Council Negri, Subversion in Sarawak, hlm. 3.

DO 187/69, Report of The Communist Threat \& Local Chinese Problems in Sarawak \& Sabah with Recommendations, by Head, Psychological Warfare Section, Ministry of Internal Security, Government of Malaysia, December 1963, Kuala Lumpur.

CO 947/32, Paper for the Information of the Malaysia Commission, 196062. Lihat juga Mohd. Reduan Haji Asli, Pemberontakan Bersenjata Komunis di Malaysia, hlm. 78.

Justus M. Van Der Kroef, "Communism and Chinese Communalism in Sarawak", hlm. 42.

The Straits Times, 4 May 1962, hlm. 7; The Sarawak Tribune, 4 August 1960, hlm. 1; Sarawak By The Week, 17 July-23 July 1960, hlm. 6-7. Lihat juga CO 947/32, Paper for the Information of the Malaysia Commission, 1960-62; Vernon L. Porritt, British Colonial Rule in Sarawak, 1946-1963, hlm. 83-84. Lihat The Straits Times, 4 May 1962, hlm. 7.

Communism and The Farmers, Kuching: The Government of Sarawak, November 1961, hlm. 7-8; Sarawak By The Week, 26 November-2 December 1961, hlm. 2; The Borneo Bulletin, 12 August 1961, hlm. 3.

Sarawak By The Week, 26 November-2 December 1961, hlm. 1.

Communism and The Farmers, hlm. 1 dan 5-6. Lihat juga Sarawak Information Service, The Danger Within: A History of the Clandestine Communist Organisation in Sarawak, Kuching: Government Printing Office, 1963, hlm. 21; Vernon L. Porritt, The Rise and Fall of Communism in Sarawak, 
1940-1990, hlm. 44-45; Mohd. Reduan Haji Asli, Pemberontakan Bersenjata Komunis di Malaysia, hlm. 80-81.

33 Communism and The Farmers, hlm. 2.

$34 \quad$ The Communist Threat to Sarawak, hlm. 7.

35 Apabila penjajah British memperkenalkan pilihan raya tempatan di Sarawak pada tahun 1956 dan akan disusuli dengan pilihan raya negeri yang pertama, orang Cina mula bergerak untuk menyatukan komunitinya dalam sebuah parti politik. SUPP ditubuhkan pada 12 Jun 1959 dengan diketuai oleh Ong Kee Hui dan Stephen Yong sebagai Setiausaha. Penubuhan SUPP dibenarkan oleh Gabenor Sarawak sebagai sebuah parti berbilang kaum tetapi parti ini telah dimonopoli oleh orang Cina. Untuk memperluaskan pengaruhnya, SUPP telah menubuhkan cawangan dan ranting parti di seluruh Sarawak. Pada tahun 1961, SUPP mendakwa telah mempunyai lebih 45,000 ahli dengan 46 cawangan dan ranting yang dibentuk di seluruh Sarawak. Ho Hui Ling, "Orang Cina dan Penglibatan Dalam Politik di Negeri Sarawak, 1841-1963", Sejarah, Jurnal Jabatan Sejarah Universiti Malaya, No. 20, 2012, hlm. 18-19. Lihat juga Micheal B. Leigh, The Rising Moon: Political Change in Sarawak, Sydney: Sydney University Press, 1974, hlm. 8-21; Craig A. Lockard, "Parties, Personalities and Crisis Politics in Sarawak", JSEAH, Vol. 8, No. 1, March 1967, hlm. 114. Rujuk juga CO 947/35, Written Representations Kuching (English Language); Sarawak By The Week, 26 November-2 December 1961, hlm. 4; The Borneo Bulletin, 9 December 1961, hlm. 2. Sarawak Information Service, The Danger Within, hlm. 28-29.

Ibid., hlm. 25.

The Straits Times, 31 July 1962, hlm. 6. Lihat juga Justus M. Van Der Kroef, "Communism and Chinese Communalism in Sarawak", hlm. 38.

The Sarawak Tribune, 5 January 1963, hlm. 1. Hubungkait antara CCO dengan SUPP turut dinyatakan dalam Justus M. Van Der Kroef, "Communism and Chinese Communalism in Sarawak", hlm. 43-46; Justus M. Van Der Kroef, "Communism in Sarawak Today", hlm. 572-574. Sarawak By The Week, 9 June-15 June 1963, hlm. 1; The Sarawak Tribune, 10 June 1963, hlm. 1.

$41 \quad$ Utusan Sarawak, 21 June 1962, hlm. 1.

42 The Borneo Bulletin, 23 June 1962, hlm. 1.

43 Hara Fujio, "Wen Ming Chyuan: Chairman of the North Kalimantan Communist Party", $3^{\text {rd }}$ Nicholas Tarling Conference on Southeast Asian Studies, 12-13 November 2013, Faculty of Arts and Social Sciences, University of Malaya, Kuala Lumpur, hlm. 269-271. Justus M. Van Der Kroef, "Communism and Chinese Communalism in Sarawak", hlm. 58-59.

$45 \quad$ Ibid., hlm. 63.

46 DO 169/486, Sarawak Fortnightly Political and Economic Summary 8-21 April 1965.

47 DO 169/486, Sarawak Fortnightly Political and Economic Summary For The Period Ending 24 ${ }^{\text {th }}$ February 1965; DO 169/486, Sarawak Fortnightly Political and Economic Summary For The Period Ending 10 ${ }^{\text {th }}$ March 1965; 
DO 169/486, Sarawak Fortnightly Political and Economic Summary 8-21 April, 1965; DO 169/486, Sarawak Fortnightly Political and Economic Summary 22 April-5 May, 1965; DO 169/486, Sarawak Fortnightly Political and Economic Summary 6-19 May, 1965; DO169/486, Sarawak Fortnightly Political and Economic Summary 2-15 June, 1965; DO 169/486, Sarawak Fortnightly Political and Economic Summary 30 June-13 July, 1965. DO 187/69, The Robinson Report An Account of Psychological Operations in The Area of Operation Hammer. Lihat juga DO 169/486, Sarawak Fortnightly Political and Economic Summary 30 June-13 July 1965; DO 169/486, Sarawak Fortnightly Political and Economic Summary 14-27 July 1965. Guardian, 8 July 1965, DO 169/435, Report of The Committee (B) on Regrouping and Resettlement in Borneo (Goodsir Report). DO 187/69, The Robinson Report An Account of Psychological Operations in The Area of Operation Hammer. Lihat juga DO 187/69, G.F.N. Reddaway, J.M.A. Bottomley, Esq., British High Commission, Kuala Lumpur, to Office of the Political Adviser to the Commander-in-chief, Far East, Phoenix Park, Singapore, 13 December 1965; The Borneo Bulletin, 10 July 1965, DO 169/435, Report of The Committee (B) on Regrouping and Resettlement in Borneo (Goodsir Report). "Operation Hammer" dirancang oleh Sarawak State Security Executive Committee dengan mendapatkan kebenaran daripada Kerajaan Malaysia. Gerakan itu melibatkan 1,500 orang tentera, polis dan penjawat awam. Yorkshire Post. DO 169/435, Report of The Committee (B) on Regrouping and Resettlement in Borneo (Goodsir Report).

DO 169/486, Sarawak Fortnightly Political and Economic Summary 14-27 July 1965.

DO 169/486, Sarawak Fortnightly Political and Economic Summary 30 June-13 July 1965; DO 169/486, Sarawak Fortnightly Political and Economic Summary 14-27 July 1965. DO187/69, C.S. Carlisle, S.A. Budd, Esq., British High Commission, Kuala Lumpur, to Office of the British Deputy High Commissioner, Kuching, $8^{\text {th }}$ March 1966. Yorkshire Post. DO 169/435, Report of The Committee (B) on Regrouping and Resettlement in Borneo (Goodsir Report). The Threat of Armed Communism in Sarawak, Kuala Lumpur: Jabatan Chetak Kerajaan, 1972, hlm. 12-13.

56 Ho Hui Ling, "Orang Cina dan Penglibatan Dalam Politik di Negeri Sarawak, 1841-1963", hlm. 19. Lihat juga The Sarawak Tribune, 31 May 1961, hlm. 1; The Borneo Bulletin, 3 June 1961, hlm. 1; 9 June 1962, hlm. 2; Nanyang Siang Pau, 27 August 1996, hlm. A8; The Vanguard, 11 July 1971, hlm. 1.

57 Justus M. Van Der Kroef, "Communism in Sarawak Today", hlm. 572-573.

58 Visit To Sarawak $\left(18^{\text {th }}\right.$ and $19^{\text {th }}$ May, 1967) by Dr. L.W. Jayesuria, Kementerian Kesihatan KK (S)-614(8), bil: 19, Kementerian Pertahanan Malaysia Indonesia/Malayan Border Control. 
Appendix ' $\mathrm{D}$ ' dan Annexure ' $\mathrm{C}$ ', Perbendaharaan Malaysia, Bahagian Belanjawan, 0.8997/37-4 (SSR), Cawangan Khas Kontigen Sabah/Sarawak Rascom.

60 The Borneo Post, 11 March 2012. Lihat juga The Threat of Armed Communism in Sarawak, hlm. 25-26.

61 Hara Fujio, "The North Kalimantan Communist Party: Preliminary Study", hlm. 200-201.

62 An Appreciation of Security Situation, Functions, Problems, and Workloads Faced by Special Branch RASCOM, 9 April 1976, Perbendaharaan Malaysia, Bahagian Belanjawan, 0.8997/37-4 (SSR), Cawangan Khas Kontigen Sabah/Sarawak Rascom.

63 Vernon L. Porritt, The Rise and Fall of Communism in Sarawak 1940-1990, hlm. 195; Penyata Rasmi, Dewan Rakyat, Parlimen Ketiga, Penggal Parlimen Kedua, Jilid II, Bil. 48, 29hb Januari 1973, hlm. 6066-6067. Mejar Jeneral Dato Nordin Yusof, Abdul Razak Abdullah Baginda, Maruah $\mathcal{E}$ Pengorbanan: Angkatan Tentera Malaysia, Kuala Lumpur: Angkatan Tentera Malaysia, Kementerian Pertahanan, 1994, hlm. 17. An Appreciation of Security Situation, Functions, Problems, and Workloads Faced by Special Branch RASCOM, 9 April 1976, Perbendaharaan Malaysia, Bahagian Belanjawan, 0.8997/37-4 (SSR), Cawangan Khas Kontigen Sabah/Sarawak Rascom. Command Structure, $2^{\text {nd }}$ Bureau NCKP, HQ Central Command Unit, Perbendaharaan Malaysia, Bahagian Belanjawan, 0.8997/37-4 (SSR), Cawangan Khas Kontigen Sabah/Sarawak Rascom. The Borneo Post, 20 September 1978, hlm. 1.

68 The Borneo Post, 11 March 2012, hlm. 3.

69 The Borneo Post, 22 April 2012; The Sarawak Tribune, 4 March 1974, hlm. 7. Lihat juga Sri Aman, Peace Restored in Sarawak, Kuching: Malaysian Information Service, 1974, hlm. 3; Mohd. Reduan Haji Asli, Pemberontakan Bersenjata Komunis di Malaysia, hlm. 192; Vernon L. Porritt, The Rise and Fall of Communism in Sarawak, 1940-1990, hlm. 209-210.

70 Sarawak 30 Years of Independence within Malaysia 1993, Kuching: Malaysian Information Services Department, t.t., hlm. 314. Menurut Mohd. Reduan Haji Asli, Pemberontakan Bersenjata Komunis di Malaysia, hlm. 192, seramai 585 orang komunis menyerah diri. Manakala, Appendix ' $G$ ', hlm. 11, Perbendaharaan Malaysia, Bahagian Belanjawan, 0.8997/37-4 (SSR), Cawangan Khas Kontigen Sabah/Sarawak Rascom, mencatatkan angka 563 orang.

$71 \quad$ Sarawak 30 Years of Independence within Malaysia 1993, hlm. 314 dan 315. 